\title{
Clinical mastitis in ewes; bacteriology, epidemiology and clinical
} features

\author{
Tormod Mørk*1, Steinar Waage ${ }^{2}$, Tore Tollersrud ${ }^{1}$, Bjørg Kvitle ${ }^{1}$ and \\ Ståle Sviland ${ }^{1}$
}

Address: ${ }^{1}$ Department of Animal Health, National Veterinary Institute, PO Box 8156 Dep, N-0033 Oslo, Norway and ${ }^{2}$ Department of Production Animal Clinical Sciences, Norwegian School of Veterinary Science, PO Box 8146 Dep, N-0033 Oslo, Norway

Email: Tormod Mørk* - tormod.mork@vetinst.no; Steinar Waage - steinar.waage@veths.no; Tore Tollersrud - tore.tollersrud@vetinst.no; Bjørg Kvitle - bjorg.kvitle@vetinst.no; Ståle Sviland - stale.sviland@vetinst.no

${ }^{*}$ Corresponding author

Published: 24 September 2007

Acta Veterinaria Scandinavica 2007, 49:23 doi:10.1186/1751-0147-49-23

This article is available from: http://www.actavetscand.com/content/49/1/23

(C) 2007 Mørk et al; licensee BioMed Central Ltd.

This is an Open Access article distributed under the terms of the Creative Commons Attribution License (http://creativecommons.org/licenses/by/2.0), which permits unrestricted use, distribution, and reproduction in any medium, provided the original work is properly cited.
Received: 8 April 2007

Accepted: 24 September 2007

\begin{abstract}
Background: Clinical mastitis is an important disease in sheep. The objective of this work was to identify causal bacteria and study certain epidemiological and clinical features of clinical mastitis in ewes kept for meat and wool production.

Methods: The study included 509 ewes with clinical mastitis from 353 flocks located in 14 of the 19 counties in Norway. Clinical examination and collection of udder secretions were carried out by veterinarians. Pulsed-field gel electrophoresis (PFGE) was performed on 92 Staphylococcus aureus isolates from 64 ewes.
\end{abstract}

Results and conclusion: S. aureus was recovered from $65.3 \%$ of 547 clinically affected mammary glands, coagulase-negative staphylococci from $2.9 \%$, enterobacteria, mainly Escherichia coli, from 7.3\%, Streptococcus spp. from 4.6\%, Mannheimia haemolytica from I.8\% and various other bacteria from $4.9 \%$, while no bacteria were cultured from $13.2 \%$ of the samples. Forty percent of the ewes with unilateral clinical $S$. aureus mastitis also had a subclinical $S$. aureus infection in the other mammary gland. Twenty-four of $28(86 \%)$ pairs of S. aureus isolates obtained from clinically and subclinically affected mammary glands of the same ewe were indistinguishable by PFGE. The number of identical pairs was significantly greater than expected, based on the distribution of different S. aureus types within the flocks. One-third of the cases occurred during the first week after lambing, while a second peak was observed in the third week of lactation. Gangrene was present in $8.8 \%$ of the clinically affected glands; S. aureus was recovered from $72.9 \%$, Clostridium perfringens from $6.3 \%$ and $E$. coli from $6.3 \%$ of the secretions from such glands. This study shows that $S$. aureus predominates as a cause of clinical ovine mastitis in Norway, also in very severe cases. Results also indicate that $S$. aureus is frequently spread between udder halves of infected ewes.

\section{Background}

Mastitis is an important disease in sheep. Clinical cases are often severe; systemic signs are present and the condi- tion is obviously painful. Clinically affected glands frequently suffer partial or complete damage and do not resume normal function. Reduced milk yield leads to 
decreased growth of the lambs [1-3]. Additional losses associated with clinical mastitis are costs of treatment and culling of ewes due to permanent udder damage [3-7]. In very severe cases, gangrene may develop in the mammary gland and the ewe may die. Thus, mastitis has a major impact on both economy and animal welfare in sheep production.

Although a wide range of microorganisms may cause ovine mastitis, most cases are reported to be due to staphylococci [8]. Several reports indicate that coagulasenegative staphylococci (CNS) are the most common cause of subclinical mastitis in dairy ewes [9-14], while both CNS and Staphylococcus aureus are frequent causes in meat sheep $[5,15,16]$. With regard to organisms associated with clinical mastitis, there are fewer reports published. $S$. aureus has been reported to be the most common causal organism in both meat $[5,15,17-19]$ and dairy ewes $[13,20,21]$. Mannheimia haemolytica $[5,18,19,22]$, Escherichia coli $[13,18,19]$ and various streptococci $[15,18,19]$ are other important causative organisms.

Differences in climate, production forms and management practices may give rise to differences both in the epidemiology, bacteriology and clinical manifestations of mastitis. In Norway, sheep are kept exclusively for meat and wool production. They are housed during the winter and early spring, including the lambing season.

The objective of this study was to identify bacteria associated with clinical ovine mastitis in Norway. In addition, certain epidemiological and clinical features of the disease were studied.

\section{Methods}

\section{Animals and clinical data}

Udder secretions were collected and clinical data recorded from 509 ewes with clinical mastitis. The ewes belonged to 353 flocks located in 14 counties in Norway (Figure 1). The geographical distribution of the cases is shown in Table 1. Clinical mastitis was present in one gland in 471 ewes and in both glands in 38 ewes. The study was carried out in 2002, 2003 and 2004. Only cases that occurred between 1 week prepartum and 8 weeks postpartum were included. In Norway, lambing generally takes place in April and May.

\section{Data and sample collection}

Thirty-two veterinary practitioners contributed to the study. When called to a case of clinical mastitis, the veterinarian was to examine the ewe, collect udder secretions and record information regarding the identity, age, date of parturition, the number of lambs and the clinical condition of the ewe on a standardized form. Clinical data included the rectal temperature, an assessment of the
Table I: Distribution by region and county of 547 milk samples obtained from ovine mammary glands with clinical mastitis, and of the 509a ewes and 353 flocks from which the samples originated.

\begin{tabular}{lrrrr}
\hline Region & County & $\begin{array}{r}\text { No. of } \\
\text { flocks }\end{array}$ & $\begin{array}{r}\text { No. of } \\
\text { ewes }\end{array}$ & $\begin{array}{r}\text { No. of } \\
\text { glands }\end{array}$ \\
\hline \multirow{2}{*}{ East } & Akershus & 13 & 27 & 31 \\
& Hedmark & 68 & 121 & 128 \\
& Oppland & 60 & 85 & 86 \\
South & Buskerud & 4 & 5 & 6 \\
& Aust-Agder & 34 & 56 & 57 \\
\multirow{4}{*}{ West } & Vest-Agder & 4 & 6 & 7 \\
& Rogaland & 40 & 48 & 53 \\
& Hordaland & 22 & 26 & 28 \\
& Sogn og Fjordane & 25 & 25 & 29 \\
& Møre og Romsdal & 32 & 39 & 40 \\
& Sør-Trøndelag & 33 & 46 & 50 \\
& Nord-Trøndelag & 6 & 10 & 13 \\
& Nordland & 3 & 3 & 4 \\
& Troms & 9 & 12 & 15 \\
\hline
\end{tabular}

a Four hundred and seventy-one ewes with unilateral and 38 with bilateral intramammary infection.

severity of systemic signs (graded as none, weak, moderate or severe) and local clinical signs of the affected gland, including whether or not gangrene was present (i.e., cold and blue udder and teat skin).

Prior to treatment, samples were collected aseptically from the clinically affected glands in $10-\mathrm{ml}$ sterile plastic vials by the veterinary practitioner according to the International Dairy Federation's standards [23]. Additionally, samples were taken from the clinically unaffected gland of 252 of the ewes with unilateral clinical mastitis. The samples were sent by mail to the laboratory as soon as possible after sampling, or frozen and stored at $-20^{\circ} \mathrm{C}$ until submission.

If a ewe experienced more than one episode of mastitis during the observation period, only the first episode was included in the study.

\section{Microbiological methods}

The samples were examined at the National Veterinary Institute or at the TINE Mastitis Laboratory in Molde, Norway, and bacteria were identified according to the recommendations of the International Dairy Federation [23] with additions. The National Veterinary Institute and the TINE Mastitis Laboratory are both quality assured in accordance with NS-EN ISO/IEC 17025. Briefly, the secretions were brought to room temperature, assessed visually and characterized by appearance before they were mechanically shaken and $10 \mu$ plated on Bacto Blood Agar Base No 2 (Difco Laboratories, Detroit, MI, USA) containing $5 \%$ washed bovine erythrocytes and incubated 


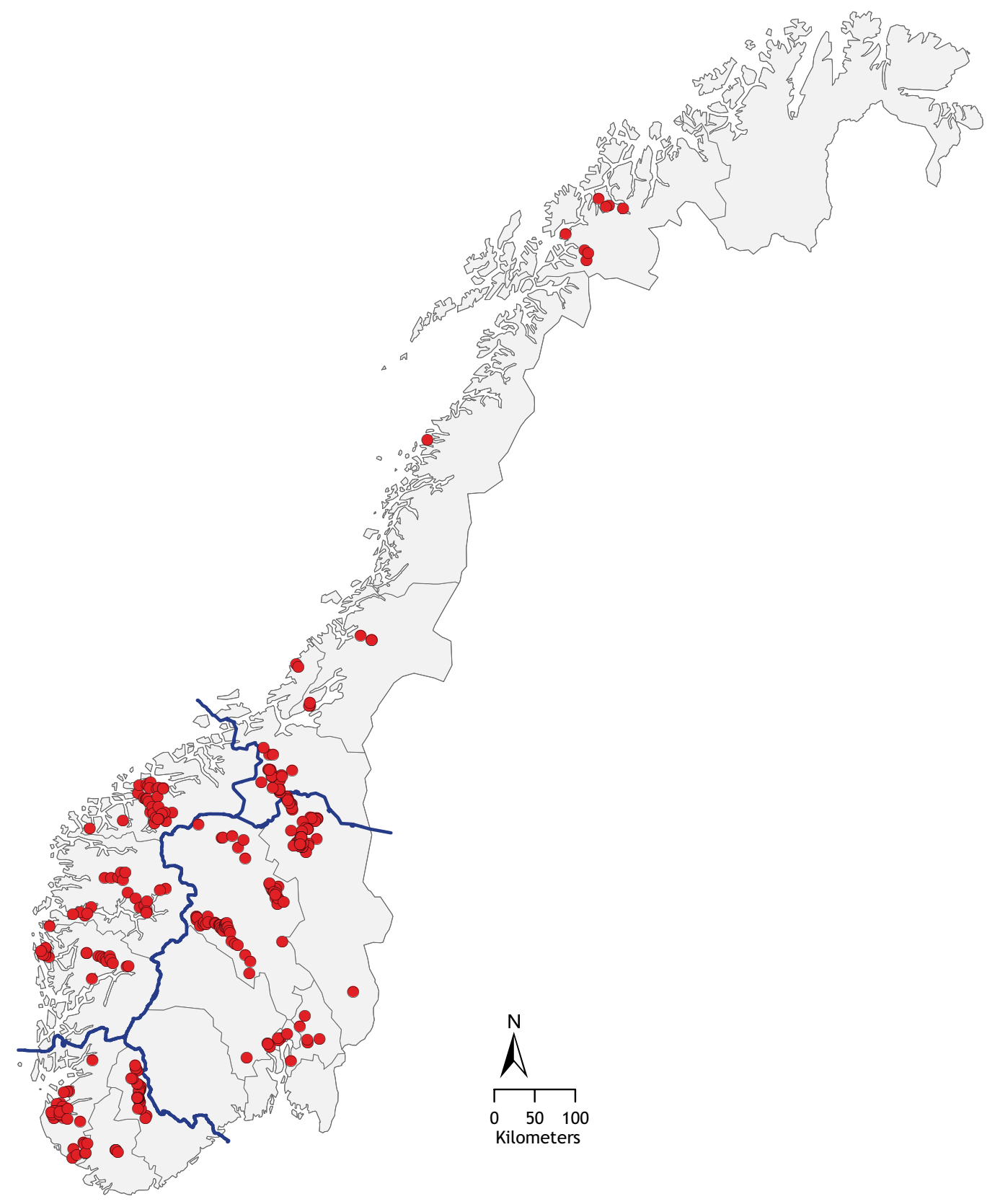

Figure I

Map of Norway showing the location of the sheep flocks from which cases of clinical mastitis were obtained. Thin lines show county boundaries and thick lines region boundaries. 
for 48 hours in a $5 \% \mathrm{CO}_{2}$ atmosphere at $37^{\circ} \mathrm{C}$. Cultures were read at 24 and 48 hours. If growth was not detected after incubation for 24 hours, the original sample was incubated for 4 hours at $37^{\circ} \mathrm{C}$ and $50 \mu$ aliquots plated and incubated for 24 hours under aerobic $\left(5 \% \mathrm{CO}_{2}\right.$ atmosphere) and anaerobic conditions.

Bacterial species were identified tentatively by their gross colony morphology and by Gram staining, and further confirmatory tests were used as necessary. All suspected staphylococcal colonies were tested using the tube coagulase test (Becton Dickinson Microbiology Systems, Bedford, MA, USA). Coagulase-positive staphylococci were streaked on peptone agar (p-agar) (Difco, Sparks, MD) supplemented with $7 \mathrm{mg} / \mathrm{l}$ of acriflavin (Sigma-Aldrich Chemie, Steinheim, Germany) [24], and incubated at $37^{\circ} \mathrm{C}$ for 24 hours. Bacterial growth in the full length of the streak on p-agar was considered confirmative of $S$. aureus. Isolates identified as $S$. aureus were stored at $-70^{\circ} \mathrm{C}$ in Bacto Heart Infusion Broth (Difco) with $15 \%$ glycerol. $E$. coli was identified by the lactose and indole tests, and other enterobacteria were identified to the species or genus level by using a microtube identification system (API 20 E $^{\circledR}$; bioMérieux S.A., Marcy-l'Etoile, France). Streptococcus uberis, Streptococcus dysgalactiae, Streptococcus agalactiae, Streptococcus spp. and Enterococcus spp. were distinguished by the CAMP reaction, the aesculin and inulin tests and by culture on the bromthymolblue lactosesucrose agar. Bacteria within the family Pasteurellaceae were identified to the species level by the CAMP reaction, the indole, mannitol, sorbitol, trehalose, dulcitol, oxidase and beta-galactosidase tests and the haemolysis patterns. Clostridium perfringens was differentiated from other Clostridium spp. by colony morphology, immobility and the presence of a zone of partial haemolysis and a zone of complete haemolysis. Arcanobacterium pyogenes was identified by Gram staining and the presence of pinpoint colonies surrounded by a narrow zone of clear haemolysis at 48 hours. None of the samples were from ewes with arthritis, conjunctivitis or pneumonia; therefore, the mammary secretions were not checked for the presence of mycoplasms.

Total DNA was prepared and pulsed-field gel electrophoresis (PFGE) performed as described previously [25] on $92 \mathrm{~S}$. aureus isolates from 21 flocks in which at least one ewe had bilateral $S$. aureus intramammary infection (IMI) and where at least two ewes experienced clinical $S$. aureus mastitis. The band patterns were compared visually. Isolates with indistinguishable patterns were considered identical PFGE types while those with at least one band difference were considered to be different types.

\section{Statistical methods}

The chi-square test was used to compare the frequencies of cases within different time intervals in relation to parturition and the relative proportions of clinical $S$. aureus cases and gangrenous mastitis cases in ewes of different parity and with different number of lambs.

The distribution of pairs of $S$. aureus PFGE types within flocks (equal vs. unequal) in ewes with bilateral IMI was compared with the corresponding distribution that would be expected if all $S$. aureus isolates found within each flock were paired randomly. All isolates from the flocks that supplied two or more cases of clinical $S$. aureus mastitis, of which at least one ewe had bilateral IMI, were included, and Fisher's exact test was used to test the probability of identical distributions of the observed and expected pairs.

$P<0.05$ was considered statistically significant.

\section{Results}

\section{Bacteriological and epidemiological findings}

The distribution of bacteria cultured from secretions from the glands with clinical mastitis is shown in Table 2. S. aureus was the predominant pathogen and was found in $65.3 \%$ of the samples from affected glands. In the samples from the southern, eastern, western and northern regions, S. aureus was found in $76.0 \%, 59.0 \%, 63.9 \%$ and $69.5 \%$, respectively.

Information about the date of parturition was received from 318 of the 471 cases of unilateral clinical mastitis. The distribution of the observed clinical mastitis cases in

Table 2: Results of culture of secretions recovered from 547 mammary glands with clinical mastitis.

\begin{tabular}{|c|c|c|}
\hline Bacteriological finding & $\mathrm{n}$ & $\%$ \\
\hline Staphylococcus aureus & 357 & 65.3 \\
\hline Coagulase-negative staphylococci & 16 & 2.9 \\
\hline Streptococcus uberis & 9 & 1.6 \\
\hline Streptococcus dysgalactiae ${ }^{a}$ & 8 & 1.5 \\
\hline Streptococcus spp. ${ }^{b}$ & 8 & 1.5 \\
\hline Enterococcus spp. & 4 & 0.7 \\
\hline Escherichia coli & 35 & 6.4 \\
\hline Klebsiella pneumoniae & 2 & 0.4 \\
\hline Enterobacter spp. & 3 & 0.5 \\
\hline Mannheimia haemolytica & 10 & 1.8 \\
\hline Arcanobacterium pyogenes & 4 & 0.7 \\
\hline Clostridium perfringens & 7 & 1.3 \\
\hline Pasteurella spp. ${ }^{c}$ & 4 & 0.7 \\
\hline No growth & 72 & 13.2 \\
\hline Contaminated samples ${ }^{d}$ & 8 & 1.5 \\
\hline
\end{tabular}

a Subsp. dysgalactiae.

b Other than Str. dysgalactiae and Str. uberis.

c Pasteurella mairii (2 samples), Pasteurella multocida (2 samples).

$d$ If blood agar plates contained more than two different types of colonies. 
relation to the time of parturition is shown in Figure 2. The relative proportion of cases was greatest during the first week after lambing. Sixty-four (20.1\%) of the 318 ewes for which the times of lambing and treatment were recorded, were treated for clinical mastitis during the first two days after parturition. The proportion of cases was significantly greater in the first $(P<0.005)$ and the third $(P<$ $0.05)$ week postpartum as compared with the second week postpartum.

The proportion of the clinical S. aureus cases among all the clinical cases did not differ significantly between weeks of lactation, between ewes of different parities or between ewes with different number of lambs (data not shown).

In 180 ewes with unilateral clinical S. aureus mastitis, from which samples from both mammary glands were examined, S. aureus was found in secretions from 72 $(40.0 \%)$ of the glands without clinical signs. In 72 ewes with unilateral clinical mastitis not caused by $S$. aureus, a subclinical $S$. aureus infection was found to be present in $10(13.9 \%)$ of the glands without clinical signs.

\section{S. aureus PFGE types in ewes with bilateral IMI}

A total of 22 different PFGE types were found among 92 $S$. aureus isolates from 21 farms. Comparisons of $S$. aureus pairs revealed that $24(86.0 \%)$ of 28 pairs had indistin- guishable band patterns (Table 3). Given the PFGE types of all S. aureus isolates within each flock, expected flockspecific distributions of PFGE type pairs based on all possible random pairwise combinations of isolates were arranged. The number of pairs with identical types observed in the flocks was significantly greater than that expected, when assuming a random distribution of isolates $(P<0.0001)$.

\section{Clinical signs}

Of the 471 cases of unilateral clinical mastitis systemic signs were recorded in 325 (Table 4) and the rectal temperature was measured in 342. Moderate or severe systemic signs were present in 159 (48.9\%) ewes and 193 $(56.4 \%)$ ewes had a rectal temperature above $40.0^{\circ} \mathrm{C}$. Thirty-seven (11.8\%) out of 313 ewes showed no systemic signs and had a rectal temperature below $40.1^{\circ} \mathrm{C}$.

Gangrene was present in $48(8.8 \%)$ of 547 clinically affected udder halves and $S$. aureus was found in 35 $(72.9 \%)$, C. perfringens in $3(6.3 \%)$, E. coli in $3(6.3 \%)$ and A. pyogenes in $1(2.1 \%)$. Bacteria were not found in 4 $(8.3 \%)$ samples from such cases and two samples were contaminated. The degree of systemic influence was recorded in 33 ewes with gangrenous mastitis. Thirty $(90.9 \%)$ of these cases exhibited moderate or severe signs. The proportion of the gangrenous mastitis cases among

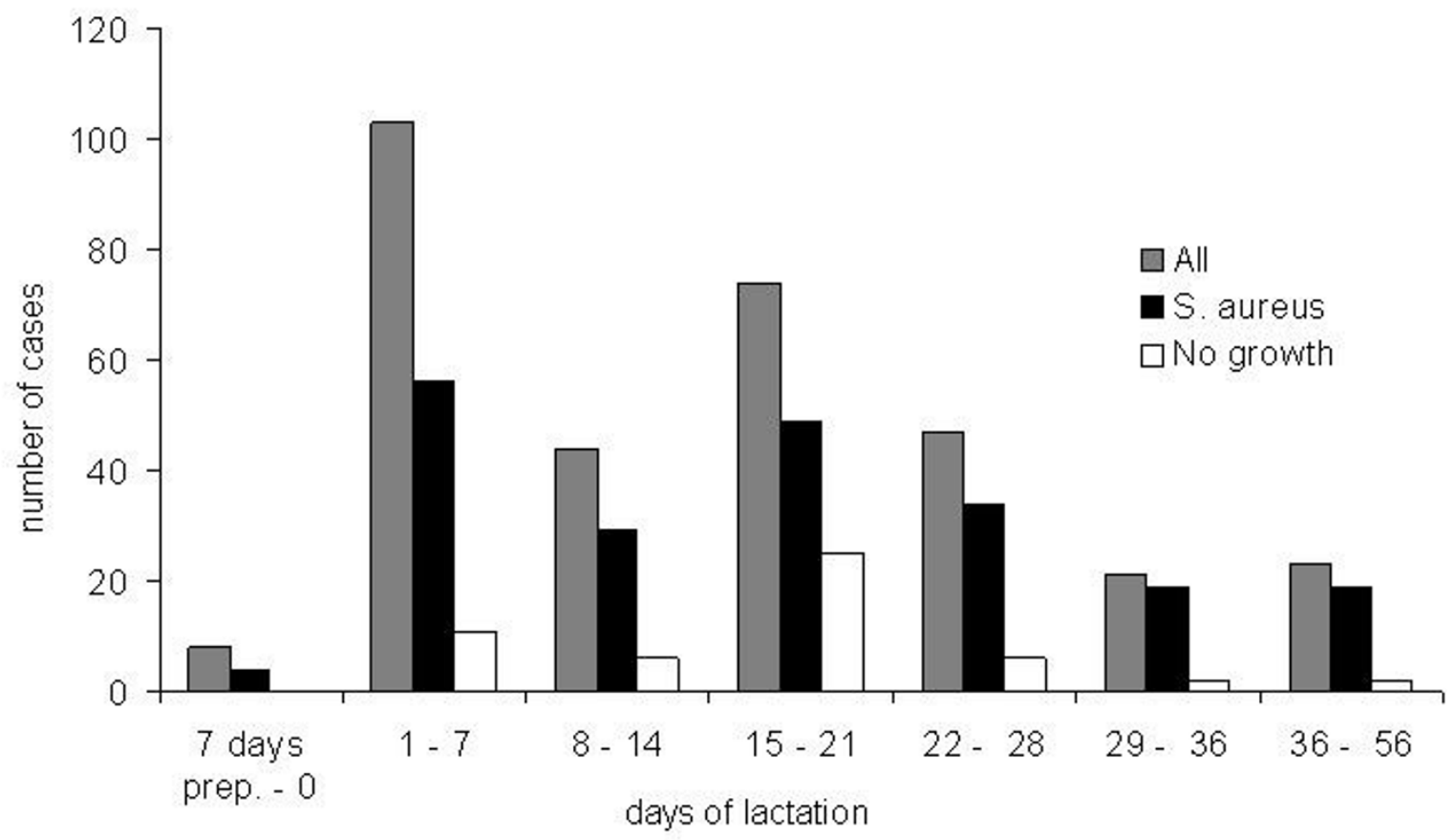

Figure 2

Distribution of 318 cases of clinical mastitis in relation to weeks of lactation. 
Table 3: Distribution within flocks of 22 different PFGE types of $92 \mathrm{~S}$. aureus isolates from ewes with intramammary infection (IMI). Only flocks in which at least one ewe experienced bilateral S. aureus IMI and two ewes experienced clinical mastitis are included. The observed pairs of PFGE types from the ewes with bilateral S. aureus IMI are shown. Also shown is the expected distribution of pairs with equal and unequal PFGE type combinations when assuming random pairwise distribution of the observed isolates within each flock.

\begin{tabular}{|c|c|c|c|c|c|}
\hline \multirow[b]{2}{*}{ Flock } & \multirow[b]{2}{*}{$\begin{array}{r}\text { Ewes } \\
\text { with IMI } \\
(n)\end{array}$} & \multirow[b]{2}{*}{$\begin{array}{r}\text { S. auerus types } \\
\text { (n) present in } \\
\text { flock }\end{array}$} & \multirow[b]{2}{*}{$\begin{array}{r}\text { Bilateral } \\
\text { PFGE type } \\
\text { combinations }\end{array}$} & \multicolumn{2}{|c|}{$\begin{array}{l}\text { Expected pairs } \\
\text { (n) }\end{array}$} \\
\hline & & & & Equal & Unequal \\
\hline $\mathrm{FI}$ & 6 & $\mathrm{~K}, \mathrm{P}, \mathrm{Q}(4), \mathrm{R}$ & QQ & 6 & 15 \\
\hline F2 & 9 & I, J, L (7), M & LL & 21 & 24 \\
\hline F3 & 2 & $R(3)$ & $\mathrm{RR}$ & 3 & 0 \\
\hline F4 & 3 & $R(4)$ & RR & 6 & 0 \\
\hline F5 & 2 & $\mathrm{H}(2), \mathrm{O}(2)$ & $\mathrm{HH}, \mathrm{OO}$ & 2 & 4 \\
\hline F6 & 2 & $D(2), H$ & DD & 1 & 2 \\
\hline F7 & 2 & $\mathrm{H}, \mathrm{I}, \mathrm{U}$ & IU & 0 & 3 \\
\hline F8 & 2 & $H(3), X$ & $\mathrm{HH}, \mathrm{HX}$ & 3 & 3 \\
\hline F9 & 2 & $\mathrm{D}, \mathrm{H}(3)$ & $\mathrm{DH}, \mathrm{HH}$ & 3 & 3 \\
\hline FIO & 2 & I, M, V & IV & 0 & 3 \\
\hline FII & 6 & $H(5), I, W$ & $\mathrm{HH}$ & 10 & II \\
\hline $\mathrm{F} / 2$ & 3 & $\mathrm{H}, \mathrm{I}(3)$ & II & 3 & 3 \\
\hline $\mathrm{FI3}$ & 3 & H (4), I (2) & $\mathrm{HH}, \mathrm{HH}, \mathrm{II}$ & 7 & 8 \\
\hline $\mathrm{FI} 4$ & 3 & $\mathrm{~F}, \mathrm{~J}(3)$ & J & 3 & 3 \\
\hline FI5 & 2 & $\mathrm{H}, \mathrm{S}(2)$ & SS & $\mathrm{I}$ & 2 \\
\hline $\mathrm{F} 16$ & 2 & $\mathrm{D}(3)$ & DD & 3 & 0 \\
\hline FI7 & 4 & $\begin{array}{r}H(2), I(2), N, \\
G(2)\end{array}$ & $\mathrm{HH}, \mathrm{II}, \mathrm{GG}$ & 3 & 18 \\
\hline FI8 & 2 & $C(2), E$ & $\mathrm{CC}$ & 1 & 2 \\
\hline F19 & 2 & $C(2), G$ & CC & I & 2 \\
\hline F20 & 3 & I (2), R, T & II & I & 5 \\
\hline F2I & 2 & $A(2), B$ & $\mathrm{AA}$ & $\mathrm{I}$ & 2 \\
\hline
\end{tabular}

all the clinical cases did not differ significantly between weeks of lactation, between ewes of different parities or between ewes with different number of lambs (data not shown).

\section{Discussion}

A random and representative selection of sheep flocks was not deemed feasible for this type of study. However, in order to have a reasonably representative geographical spread of the mastitis cases ewes from 14 of the 19 coun- ties in Norway were included. Thus, the present flocks were housed and pastured under various conditions, and the variations in climatic conditions, flock size and management routines of Norwegian sheep production were reasonably well represented. During the lambing season and subsequent weeks the ewes are paid close attention. Later, most flocks are moved to pastures in the forests or mountains. For this reason, the study was restricted to cases that occurred between 1 week prepartum and 8 weeks postpartum in order to obtain clinical cases of recent origin.

S. aureus was found in $65 \%$ of the samples from clinically affected glands. The dominance of $S$. aureus as a cause of clinical ovine mastitis has also been shown in regional studies in Norway, where $S$. aureus was isolated from udder secretions of between 64 and $87 \%$ of the ewes $[26,27]$. In the present study, the largest proportion of $S$. aureus was found in the southern region (76\%). A similar proportion of such cases (75\%) was previously observed in a study including cases from one of the municipalities of this region [28]. Studies of clinical mastitis in meat sheep in other countries have found varying, though mostly relatively great, proportions of $S$. aureus infections $(20-60 \%)[5,17-20,22]$. In a study of dairy sheep in Jordan, Lafi et al. [13] found that $22 \%$ of the clinical mastitis cases were caused by $S$. aureus.

The main $S$. aureus reservoirs in sheep are suggested to be infected mammary glands and teat lesions [29]. However, $S$. aureus can also be cultured from intact teat skin and other body sites $[10,30,31]$. In dairy flocks, transfer during milking is considered an important mechanism for the spread of this organism [29]. In flocks of meat sheep, transmission of $S$. aureus between ewes could be a result of the herdsman transmitting $S$. aureus between ewes during manual udder control, or the udder being exposed to bedding material contaminated from infected ewes $[6,7]$. Some lambs occasionally suck other ewes than their dam, which might be a mechanism for the spread of $S$. aureus [32]. In Norway, routine examination of teats and udders are performed after weaning, and ewes with palpable abnormalities or which have experienced clinical mastitis are usually slaughtered before the breeding season. This

Table 4: Distribution of 325 of the 47 I ewes with unilateral clinical mastitis by causal organism and the systemic signs ${ }^{a}$.

\begin{tabular}{lccccc}
\hline Pathogen & I & 2 & 3 & 4 & Total \\
& No. (\%) & No. (\%) & No. (\%) & No. (\%) \\
All & $51(15.7)$ & $115(35.4)$ & $119(36.6)$ & $40(12.3)$ & 325 \\
S. aureus & $30(13.5)$ & $77(34.5)$ & $89(39.9)$ & $27(12.1)$ & 223 \\
Enterobacteria & $2(7.7)$ & $9(34.6)$ & $11(42.3)$ & $4(15.4)$ & 26 \\
No growth & $11(34.4)$ & $12(37.5)$ & $4(12.5)$ & $5(15.6)$ & 32 \\
\hline
\end{tabular}

$a_{1}=$ no systemic signs, 2 = weak systemic signs, 3 = moderate systemic signs, 4 = severe systemic signs. 
contributes to decreasing the reservoir of $S$. aureus, but it obviously does not eliminate it.

Studies in other countries have reported prevalences of subclinical $S$. aureus IMI to be between 1 and $6 \%$ $[12,13,15,33]$. This indicates that subclinically infected glands are an important reservoir of $S$. aureus that can only be detected through bacteriological examination. In this study, $14 \%$ of the ewes with unilateral clinical mastitis caused by other pathogens than $S$. aureus had a subclinical $S$. aureus infection in the other mammary gland, while $40 \%$ of the ewes with clinical S. aureus infection in one gland had a subclinical $S$. aureus infection in the other. PFGE typing showed that $86 \%$ of the pairs of isolates from ewes with bilateral $S$. aureus IMI were indistinguishable. This percentage was much higher than what would be expected if the isolates from each of the flocks were paired at random, thus demonstrating a considerably greater tendency for spread of $S$. aureus between the udder halves of a ewe than between ewes within a flock.

The very low percentage of $M$. haemolytica in the clinically affected glands in this study $(1.8 \%)$ contrasts results of clinical mastitis surveys in meat sheep in the UK and Ireland, where the proportions of cases caused by this organism were found to be approximately $50 \%$ and $21 \%$, respectively $[5,18]$. Enterobacteria, mainly E. coli, were obtained from $7.3 \%$ of the clinically affected udder halves, which is similar to the proportions found in other studies on meat sheep $[5,18,22]$. However, the number of clinical cases caused by Gram negative bacteria and A. pyogenes may be underestimated because the samples were frozen before bacteriological analysis [34,35].

It is noteworthy that nearly $85 \%$ of the ewes exhibited systemic signs and that gangrene was present in as much as $9 \%$ of the clinically affected udder halves, clearly showing that ovine clinical mastitis must be considered a serious animal welfare problem. However, mild cases of clinical mastitis are most likely underrepresented in this study. According to Norwegian legislation, antibiotic treatment of animals must be initiated by a veterinarian and, for economical reasons, farmers might be reluctant to call for a veterinary surgeon to treat mild clinical cases.

Most mastitis cases occurred close to lambing. One-third of the ewes developed clinical mastitis during the first week after lambing, and a second peak, although somewhat smaller, was observed in the third week postpartum. This is in accordance with data from the Norwegian Sheep Recording System [36]. Likewise, studies in the UK and Ireland found that cases of acute clinical mastitis occurred most frequently during the first week of lactation, while a second peak occurred between the third and fourth week [5] or the fourth and seventh week [18] after lambing.
Clinical cases around parturition might be newly acquired IMI or aggravations of existing subclinical infections [37]. The proportion of very severe cases, in which gangrene had developed, was not greater among cases occurring close to lambing as compared with those occurring later. The second peak could be explained by increased milk demand from the lambs and the eruption of incisors, which increases the risk of teat lesions. It has been reported that teat lesions frequently are present in ewes with clinical mastitis three to four weeks after lambing [38].

\section{Conclusion}

This study shows that $S$. aureus is the most common cause of clinical mastitis in sheep in Norway and that this organism is frequently spread between glands in infected ewes. Further studies identifying predisposing factors, including reservoirs, transmission routes and factors facilitating $S$. aureus infection of the ovine mammary gland, are needed in order to improve strategies to reduce the occurrence of mastitis in sheep.

\section{Competing interests}

The author(s) declare that they have no competing interests.

\section{Authors' contributions}

TM, SW, TT and SS have been involved in the design of the study and the protocols. TM has been responsible for the field project. BK, TM and SS have performed most of the microbiological work in the laboratory. BK has performed the PFGE. SW and SS have been responsible for data analysis in cooperation with TM and TT. TM drafted the manuscript, but all the authors have contributed substantially to the final manuscript. All authors have read and approved the final manuscript.

\section{Acknowledgements}

Of the veterinary surgeons who kindly contributed to the study, the authors would particularly like to thank Gunvald Mosdøl, Olav Koltveit, Grethe Steihaug, Dag Aasland, Jan I. Holøymoen, Anne Aaby, Anders Avdem, Berit C. Brændvang, Aud Solberg, Odd S. Skregelid and Knut I. Dragset.

\section{References}

I. Fthenakis GC, Jones JET: The effect of experimentally induced subclinical mastitis on milk yield of ewes and on the growth of lambs. BrVet J 1990, I 46:43-49.

2. Johnston WS, Maclachlan GK, Murray IS: A survey of sheep losses and their causes on commercial farms in the north of Scotland. Vet $\operatorname{Rec} 1980$, 106:238-240.

3. Larsgard AG, Vaabenoe A: Genetic and environmental causes of variation in mastitis in sheep. Small Rumin Res 1993, 1 2:339-347.

4. Gibson IR, Hendy PG: Mastitis in dry ewes. Vet Rec 1976, 98:5II-5I2.

5. Jones JET: Mastitis in sheep. In Breeding for Disease Resistance in Farm Animals Edited by: Owen JB, Axfor RFE. Bangor: Tucson, AZ, CAB International; 1991:412-423.

6. Kirk JH, Glenn JS: Mastitis in ewes. Compend Cont Educ Pract Vet 1996, I 8:582-59|. 
7. Watson DJ, Buswell JF: Modern aspects of sheep mastitis. Br Vet J 1984, I 40:529-534.

8. Bergonier $D$, Berthelot $X$ : New advances in epizootiology and control of ewe mastitis. Livest Prod Sci 2003, 79:1-16.

9. Ariznabarreta A, Gonzalo C, San Primitivo F: Microbiological quality and somatic cell count of ewe milk with special reference to staphylococci. J Dairy Sci 2002, 85: I370-I375.

10. Burriel AR: Dynamics of intramammary infection in the sheep caused by coagulase-negative staphylococci and its influence on udder tissue and milk composition. Vet Rec 1997, I 40:419-423.

11. Fthenakis GC: Prevalence and aetiology of subclinical mastitis in ewes of Southern Greece. Small Rumin Res 1994, 13:293-300.

12. Gonzalo C, Ariznabarreta A, Carriedo JA, San Primitivo F: Mammary pathogens and their relationship to somatic cell count and milk yield losses in dairy ewes. J Dairy Sci 2002, 85: 1460-1467.

13. Lafi SQ, Al-Majali AM, Rousan MD, Alawneh JM: Epidemiological studies of clinical and subclinical ovine mastitis in Awassi sheep in northern Jordan. Prev Vet Med 1998, 33:17|-181.

14. Pengov A: The role of coagulase-negative Staphylococcus spp. and associated somatic cell counts in the ovine mammary gland. J Dairy Sci 200I, 84:572-574.

15. Watson DL, Franklin NA, Davies HI, Kettlewell P, Frost AJ: Survey of intramammary infections in ewes on the New England Tableland of New South Wales. Aust Vet J 1990, 67:6-8.

16. Hariharan H, Donachie W, Macaldowie C, Keefe G: Bacteriology and somatic cell counts in milk samples from ewes on a Scottish farm. Can J Vet Res 2004, 68: 188-192.

17. Kryzanowski J, Wawron W, Malinowski V, Gluszak J, Orlik S: Bacterial flora isolated from the secretion of mastitic udders of ewes and their sensitivity to antibiotics. Med Vet 1983, 39:462-464.

18. Onnasch H, Healy AM, Brophy PO, Kinsella A, Doherty ML: A study of mastitis in sheep. Res Vet Sci 2002, 72:42.

19. Quinlivan TD: Survey observations on ovine mastitis in New Zealand stud Romney flocks. 2. The bacteriology of ovine mastitis. NZ Vet J 1968, 16:153-160.

20. Al-Samarrae SAG, Sharma VK, Yousif AA: Mastitis in sheep in Iraq. Vet $\operatorname{Rec} 1$ 1985, I I 6:323.

2I. Kirk JH, Glenn JS, Maas JP: Mastitis in a flock of milking sheep. Small Rumin Res 1996, 22: 187-191.

22. Bocklisch $H$, Wetzstein $D$ : Clinical, diagnostic laboratory and therapeutic studies of mastitis in a large sheep breeding flock (article in German). Tierärztl Prax 1994, 22(6):524-528.

23. International Dairy Federation: Laboratory methods for use in mastitis work Brussels: IDF, Document I32; 1981.

24. Capurro A, Concha C, Nilsson L, Östensson K: Identification of coagulase-positive staphylococci isolated from bovine milk. Acta Vet Scand 1999, 40:315-321.

25. Mørk T, Tollersrud T, Kvitle B, Jørgensen HJ, Waage S: Genetic diversity of Staphylococcus aureus isolated from ovine intramammary infections in Norway. Vet Microbiol 2005, 106:265-273.

26. Kvitrud A, Lysne I: Examinations of mastitis in sheep (article in Norwegian). Nord Vet Med 1959, I I:I 29-140.

27. Sæter $E A$, Eieland $E$ : Ovine mastitis in mountain districts in Norway (article in Norwegian). Nord Vet Med 1961, 13:32-44.

28. Indrebø A, Mosdøl G: Mastitis in the ewe. Microbiological findings and sensitivity to antibiotics (article in Norwegian). Nor Vet Tidsskr 1991, 103:107-113.

29. Vautor E, Abadie G, Guibert JM, Huard C, Pepin M: Genotyping of Staphylococcus aureus isolated from various sites on farms with dairy sheep using pulsed-field gel electrophoresis. Vet Microbiol 2003, 96:69-79.

30. Scott MJ, Jones JET: The carriage of Pasteurella haemolytica in sheep and its transfer between ewes and lambs in relation to mastitis. J Comp Pathol 1998, I I 8:359-363.

31. Vautor E, Abadie G, Guibert JM, Chevalier N, Pepin M: Nasal carriage of Staphylococcus aureus in dairy sheep. Vet Microbiol 2005, 106:235-239.

32. Bergonier D, de Cremoux R, Rupp R, Lagriffoul G, Berthelot X: Mastitis of dairy small ruminants. Vet Res 2003, 34:689-716.

33. Deutz A, Pernthaner A, Schlerka G, Baumgartner W: Investigations on cell count of milk and distribution of bacterial mastitis in
Lower Austrian sheep and goat flocks (article in German). Wien Tierärztl Mschr 1990, 77:70-77.

34. Sanchez A, Contreras A, Jimenez J, Luengo C, Corrales JC, Fernandez C: Effect of freezing goat milk samples on recovery of intramammary bacterial pathogens. Vet Microbiol 2003, 94:7I-77.

35. Schukken YH, Grommers FJ, Smit JA, Vandegeer D, Brand A: Effect of freezing on bacteriologic culturing of mastitis milk samples. J Dairy Sci 1989, 72:1900-1906.

36. Vatn S: Epidemiology of mastitis in Norwegian sheep. In Proceedings of the 6th International Sheep Veterinary Congress: I 7-2I June 2005; Hersonissos Edited by: Fthenakis GC, McKaller FA. 6th International Sheep Veterinary Congress; 2005:318-319.

37. Watkins GH, Burriel AR, Jones JET: $\mathbf{A}$ field investigation of subclinical mastitis in sheep in southern England. $B r$ Vet $J$ I99I, 147:4|3-420.

38. Indrebø A: Mastitis and teat injuries in the ewe in relation to age, partus and number of lambs (article in Norwegian). Nor Vet Tidsskr 199I, 103:197-204.
Publish with Bio Med Central and every scientist can read your work free of charge

"BioMed Central will be the most significant development for disseminating the results of biomedical research in our lifetime. "

Sir Paul Nurse, Cancer Research UK

Your research papers will be:

- available free of charge to the entire biomedical community

- peer reviewed and published immediately upon acceptance

- cited in PubMed and archived on PubMed Central

- yours - you keep the copyright

Submit your manuscript here:

http://www.biomedcentral.com/info/publishing_adv.asp
BiolMedcentral 